\title{
Recovery of gold and base metals from waste printed circuits boards
}

\author{
Recuperación de oro y metales base a partir de desechos de placas de circuitos \\ impresos

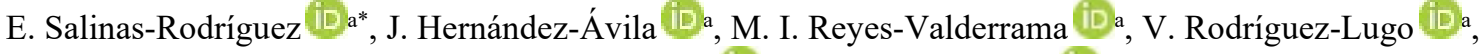 \\ J. F. Montiel-Hernández (DDb, E. Cerecedo-Sáenz (iDa \\ a Área Académica de Ciencias de la Tierra y Materiales, Universidad Autónoma del Estado de Hidalgo, 42184, Pachuca, Hidalgo, México. \\ ${ }^{\mathrm{b}}$ Escuela Superior de Ciudad Sahagún, Universidad Autónoma del Estado de Hidalgo, 43990, Cd. Sahagún, Hidalgo, México.
}

\begin{abstract}
This lab-scale experimental study presents a novel combined hydrometallurgical and electrochemical process for gold and nonprecious metals $(\mathrm{Cu}, \mathrm{Ni}, \mathrm{Pb}$ and $\mathrm{Zn})$ recovery, from waste printed circuit boards (PCB's). First, a leaching of non-precious metals from pins (contained in the PCB's) has been carried out and then a complete gold extraction was obtained using $\mathrm{H}_{2} \mathrm{SO}_{4} 0.5 \mathrm{M}(\mathrm{pH} \approx 1.5) / \mathrm{O}_{2}$ $(1 \mathrm{~atm})$ in the temperature range from 288 to $343 \mathrm{~K}$. The activation energies found showed values of $97.2 \mathrm{~kJ} \cdot \mathrm{mol}^{-1}, 86 \mathrm{~kJ} \cdot \mathrm{mol}^{-1}$ and 93.6 $\mathrm{kJ} \cdot \mathrm{mol}^{-1}$ for $\mathrm{Cu}, \mathrm{Ni}$ and $\mathrm{Zn}$ respectively and were obtained in the temperature range mentioned above. Afterwards, leaching liquor was treated electrochemically in several conditions: selective $\mathrm{Cu}$ and $\mathrm{Pb}$ removal was performed at $\mathrm{pH} 1.5$ and $\mathrm{Ni}$ and $\mathrm{Zn}$ removal was also obtained when $\mathrm{pH}$ increased to 5. All processes involved here are friendly, and even, final liquor could be reutilized for leaching and electro wining processes.
\end{abstract}

Keywords:

Gold recovery, Leaching process, Selective electrochemical recovery, Electronic waste, Printed circuit boards.

\section{Resumen}

Este estudio experimental a escala laboratorio, presenta un novedoso proceso combinado hidrometalúrgico y electrometalúrgico para la recuperación de oro y metales no preciosos $(\mathrm{Cu}, \mathrm{Ni}, \mathrm{Pb}$ y $\mathrm{Zn}$ ), a partir de desechos de placas de circuitos impresos (DPCI). Primero, se llevo a cabo una lixiviación de los metales no preciosos de los pines (contenidos en los DPCI y entonces se obtuvo una completa extracción de oro usando $\mathrm{H}_{2} \mathrm{SO}_{4} 0.5 \mathrm{M}(\mathrm{pH} \approx 1.5) / \mathrm{O}_{2}(1 \mathrm{~atm})$ en el rango de temperatura de 288 a $343 \mathrm{~K}$. Las energías de activación encontradas muestran valores de $97.2 \mathrm{~kJ} \cdot \mathrm{mol}^{-1}, 86 \mathrm{~kJ} \cdot \mathrm{mol}^{-1}$ y $93.6 \mathrm{~kJ} \cdot \mathrm{mol}^{-1}$ para $\mathrm{Cu}, \mathrm{Ni}$ y $\mathrm{Zn}$, respectivamente y fueron obtenidas en el rango de temperaturas mencionado anteriormente. Posteriormente, el licor de lixiviación fue tratado electroquímicamente en varias condiciones: la remoción selectiva de $\mathrm{Cu}$ y $\mathrm{Pb}$ se realizó a $\mathrm{PH}$ 1.5, y la remoción de $\mathrm{Ni} \mathrm{y} \mathrm{Zn} \mathrm{también} \mathrm{se}$ obtuvo cuando el pH aumentó a 5. Todos los procesos involucrados aquí son amigables con el medio ambiente e, incluso el licor final podría ser reutilizado para los procesos de lixiviación y electro recuperación.

Palabras Clave:

Recuperación de oro, Proceso de lixiviación, Recuperación selectiva electroquímica, Desechos electrónicos, Placas de circuitos impresos.

\section{Introduction}

Waste electric and electronic equipment (WEEE), or electronic waste (E-waste), has been taken into consideration by the most part of governments. E-waste is growing at a rate of 3 to $5 \%$ per annum in European Union (Schwarzer et al., 2005), around 120 $\%$ from 1990 levels in USA (US Environment Protection Agency, 2011), and a recent report released by United Nations (Schluep et al., 2009) predicted that by 2020 e-waste from old computers in South Africa and China will have jumped by $200-400 \%$ and by $500 \%$ in India compared with 2007 levels. However, the generation of reliable data on the exact amount of e-waste generated in different regions of the world is difficult to achieve as well as the amount of used WEEE reaching its end-of-life cannot be measured directly with some reliability. Most of the estimates available are based upon predictions made incorporating

\footnotetext{
*Autor para la correspondencia: salinasr@uaeh.edu.mx

Correo electrónico: salinasr@uaeh.edu.mx (Eleazar Salinas-Rodríguez), herjuan@uaeh.edu.mx (Juan Hernández-Ávila), profe_5490@uaeh.edu.mx (Ma. Isabel Reyes-Valderrama), ventura.r165@gmail.com (Ventura Rodríguez-Lugo), justo_montiel@uaeh.edu.mx (Justo F. Montiel-Hernández), mardenjazz@yahoo.com.mx (Eduardo Cerecedo-Sáenz)
} 
production or sales data, and the estimated life span of the WEEE (Herat and Agamuthu, 2012). This results in large amounts of electronic waste, which must be solved because it is becoming a major social problem and a threat to the environment. In accordance with the European waste hierarchy, national legislators and authorities being responsible for waste management, waste have to be recycled, if waste prevention or preparing waste for re-use is not possible. In the special case, waste from electric and electronic equipment, the WEEE directive (E.U., 2002) stipulates a separate collection of electric and electronic waste of a least $4 \mathrm{~kg}$ per inhabitant per year. Furthermore, European Community expects management and recycling of electronic waste contributes as a source of metals. As example, amount of copper used in 2006 at EU was 3.8 million $\mathrm{Tm}$ and amount of copper in waste was 1.8 million Tm, so waste can be seen as a resource and waste management comes into business (Friege, 2012). It can be obtained a profit up to $\$ 1400$ USD per Tm of copper recovered from waste printed circuit boards (PCB's) (Wang and Gaustad, 2012).

The composition of WEEE is function of two important conditions, which are: i) equipment and ii) year of manufacture. This waste usually consists of $30 \%$ plastics, $30 \%$ refractory oxides and $40 \%$ metals (Sodhi and Reimer, 2001). The percentage of the metals is theoretically divided as follows: $20 \% \mathrm{Cu}, 8 \% \mathrm{Fe}$, $4 \% \mathrm{Sn}, 2 \% \mathrm{Ni}, 2 \% \mathrm{~Pb}, 2 \% \mathrm{Al}, 1 \% \mathrm{Zn}, 0.1 \% \mathrm{Au}, 0.02 \% \mathrm{Ag}$, $0.005 \% \mathrm{Pd}$ and $0.875 \%$ others (Sum, 1991). From this point of view, PCB's are the basis of electric and electronic equipment, so they are the basis of WEEE (He et al., 2006), (Lee et al., 2004). The components of PCB's waste can be divided into metal fractions and non-metallic fractions and the main economic driving force for the recycling of PCB's is the value of metal fractions (Sánchez, 2010) as mentioned above. Knowing that PCB's constitute $6 \%$ of the total weight of WEEE (Guo et al., 2011), significant amount of metals is contained in WEEE, so what encourages to recycling. The PCB's should encourage, recycling. PCB's are composed by a mixture of reinforced resins and multiple types of metals even toxic plastic type materials such as polyvinyl chloride (PVC), poly(ethylene terephthalate) (PRT), and acrylonitrile-butadiene-styrene (ABS), polycarbonate (PC), Polybrominated diphenyl ethers (PBDEs), polychlorinated dibenzo-p-dioxins, dibenzofurans (PCDD/Fs), polychlorinated biphenyls (PCBs), polycyclic aromatic hydrocarbons (PAHs), flame retardants or heavy metals so recycling of these components is quite hard (Dimitrakakis et al., 2009), (Long et al., 2013), (Morf et al., 2005), (Zheng et al., 2009), (Zhou et al., 2013). However, interest in PCB's waste is focused on the large number of metals that it could be a rich source of exploitation ( $\mathrm{Li}$ et al., 2007) turning this process in part of urban mining. The recovered amount of gold per Tm of PCB's (depending on generation) is $\approx$ $250 \mathrm{~g}$, while gold ores yield of 1 to $10 \mathrm{~g}$ per Tm (Tuncuk et al., 2012); so the gains reflected per Tm of gold present in the PCB's are \$15200 USD, which is a strong economic incentive (Wang and Gaustad, 2012), (Cho et al., 2018). Furthermore, huge amounts of gold have been used on WEEE during decades due to its low electric resistance, excellent corrosion resistance and exceptional electric conductivity (Syed, 2012). As is known, PCB's are manufactured placing a gold layer on a substrate of a noble metal, such as copper, zinc or nickel and it is inserted on a polymer base.

Certainly, PCB's recycling methods are diverse and the most part of these methods involved physical and mechanical separation technologies, biotechnology treatment, super-critical fluid technology, microwave treatment and the processes of extractive metallurgy, pyrometallurgy and hydrometallurgy(Wan et al, 2018), (Işildar et al., 2018), (Cayumil et al., 2018), (Li et al., 2018) . Despite the existence of these routes mechanical crushing with hydrometallurgical processing is the predominant technology due to its high performance and competitiveness (Wang et al., 2018), (He et al., 2006), (Sánchez, 2010), (Cui and Zhang, 2008), (Ha et al., 2010), (Morera, 2004), (Reyes et al., 2012), (Zhuo and Qiu, 2010). These hydrometallurgical methods are more accurate, more predictable, easier to control and lower operation costs than other techniques (Behnamfard et al., 2013), (Yang et al., 2011), however sometimes, ecological demands are not considered (Syed, 2006). Furthermore, most of this chemical methods are limited for the use of dangerous reactants and the emissions of toxic liquors or hazardous gases to the population and environment during and after the processes (Dimitrakakis et al., 2009), (Long et al., 2013), (Li et al., 2007), (Hadi et al., 2015). For this reason, we purpose to recover the gold contained in PCB's by using an acid dynamic leaching process with sulfuric acid and oxygen. This process allows physical separation of the gold from polymer-metallic matrix and a leaching solution of non-precious metals, metallic gold is obtained.

Subsequently, non-precious metals from leaching solutions have to be removed. In this case, numerous techniques could be used, such as chemical precipitation (Blais et al., 2008) (by increasing $\mathrm{pH}$ ), ion flotation (Zamboulis et al., 2011) (using different surfactants), ion-exchange (Dąbrowski et al., 2004) (where undesirable ions are replaced by other ions which are harmless to the environment using exchange resins), membrane filtration processes (Fu and Wang, 2011) (which can be divided in ultra filtration, reverse osmosis or nano-filtration), leaching of WPCB's using bromide where most of the $\mathrm{Cu}, \mathrm{Ag}, \mathrm{Pb}, \mathrm{Au}$ and $\mathrm{Ni}$ could be dissolved simultaneously, but they did not say what happens with residues (Cui and Anderson, 2020) and adsorption (Babel and Kurniawan, 2003) (metals are transferred and accumulated at the interface between two phases). Due to increasingly stricter regulations for the discharge of effluents, conventional technique of hydroxide precipitation is limited due to cost of disposing sludge containing toxic metals is also been increased. In the same way, other named techniques are too costly and not available for all metals (Coman et al., 2013), (Hahladakis et al., 2013). For this reason, electrochemical removal of metals, cathodic treatment of leaching solutions, can substitute wasteproducing processes by a cleaner electrochemical technology with a no waste production (Haccuria et al., 2017), (Chen, 2004), (Elkhatabi et al., 1999). The removal of metals ions $\left(\mathrm{Me}^{\mathrm{n}+}\right)$ from wastewater is based on the cathodic deposition of metals:

$$
M e_{\text {sol }}^{n+}+n e^{-} \leftrightarrow M e
$$

From the thermodynamic point of view, the Nernst equation predicts that it should be possible to decrease the $\mathrm{Me}^{\mathrm{n+}}$ concentration in solution if the potential of the $\mathrm{Me} / \mathrm{Me}^{\mathrm{n}}$ electrode is maintained sufficiently negative with respect to the standard potential, so selectivity of the metal removal can be obtained choosing an appropriate potential. Nevertheless it is actually not true, potentiodynamic aspects and physicochemical conditions of the metal removal, $\mathrm{pH}$ mainly, have to be considered.

Undoubtedly, leaching and electro-wining/electro-refining process have always been attached and both became part of the first basis to establish hydrometallurgy as a formal study (Dutta et al., 2018), (Reyes-Valderrama et al., 2017), (Yang et al., 2018), (Liu et al., (2017), (Kasper et al., 2016), (Memon et al., 2017), (Zhang et al., 2018), (Mooiman et al., 2005). In order to reinforce this relationship more, if it is possible the aim of this paper which is to obtain precious metals using an environmental friendly treatment of electronic waste. Firstly, electronic waste is leached using sulfuric acid and oxygen as green process and secondly non- 
precious metals leached (mainly copper, zinc, nickel and lead) are removed selectively from leaching solutions using electrochemical processes, and clean effluent, that could be reused in leaching process.

\section{Materials and Methods}

\subsection{Procedure of pins collection and chemical characterization of solid parts}

First of all, a random collection of computing equipment of different companies, models and generations were carried out and two different PCB's were chosen in a random way. After that, manual disassemble of every pin in the PCB's was performed. Each pin was meticulously characterized by SEM-EDS using a JEOL scanning electron microscope model JSM-6300 with a solid state detector to perform energy dispersion semi-quantitative microanalysis. In addition, each solid obtained after leaching process was characterized by the same technique.

\subsection{Leaching test of electronic waste and gold recovery}

Each experiment of dynamic acid leaching for the system (Au$\mathrm{Cu}-\mathrm{Ni}-\mathrm{Zn}-\mathrm{Pb})-\mathrm{H}_{2} \mathrm{SO}_{4}-\mathrm{O}_{2}$ was performed into a conventional glass reactor of $500 \mathrm{~mL}$. First, sample ( $10 \mathrm{~g}$ of pins) was introduced into the glass reactor in a $\mathrm{H}_{2} \mathrm{SO}_{4} 0.5 \mathrm{M}$ solution $(\mathrm{pH} \approx 1.5$, nominal value), then oxygen was injected into solution using a gas diffuser during 15 minutes (pressure of $\mathrm{O}_{2}=1 \mathrm{~atm}$ ). Afterwards, reactor was set on a heating plate with magnetic stirring (stirrer of $5 \mathrm{~cm}$ ). In this sense, temperature was controlled with a tolerance of \pm $136.5 \mathrm{~K}\left(0.5^{\circ} \mathrm{C}\right)$ and rotation speed of stirrer was determined by internal magnetic control of the heating plate at 750 RPM. Furthermore, $\mathrm{pH}$ was measured in continuous way using a $\mathrm{pH}-$ meter Thermo scientific model ORION 3 STAR and it was adjusted to 1.5 adding small quantities of an aqueous solution of sulfuric acid (Figure 1). Finally, operation temperatures of 288, $298,303,308,313,318,323,333$ and $343 \mathrm{~K}$ were tested in these dynamic acid leaching experiments of 240 minutes

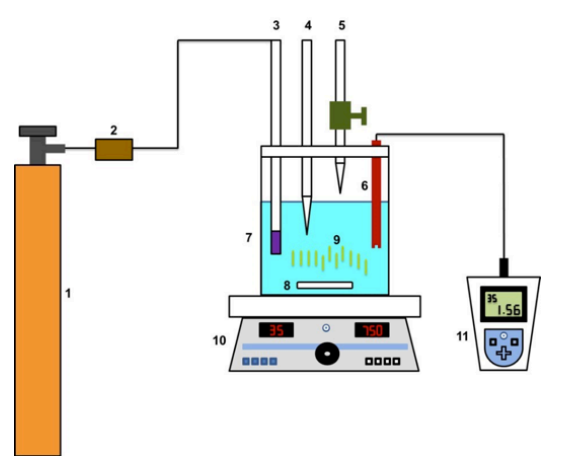

Figure 1. Scheme of the equipment used in the leaching tests: 1) Oxygen cylinder; 2) manometer; 3) oxygen diffuser; 4) graduated pipette; 5) graduated burette; 6) electrode of pH with thermal regulator; 7) glass reactor with a flat cover; 8) stirrer; 9) e-waste; 10) heating plate with magnetic stirring; and 11) $\mathrm{pH}$ meter

Once reaction was started, supernatant samples at different times were collected to analyze progress of the experiment. In this case, non-precious metals were analyzed by atomic absorption spectroscopy (AAS) using a spectrophotometer Perkin Elmer model 2380. At the end, final mixture of leaching solution and solids were chemical characterized as was said: mainly (gold) by
SEM-EDS and leaching solution (non-precious metals solutions) by ASS.

\subsection{Removal of non-precious metals from leaching solution using electrochemical processes}

Removal of non-precious metals was carried out using a filter press electrochemical reactor. The electrochemical reactor, with an electrode area of $63 \mathrm{~cm}^{2}$, was constituted by a threedimensional cathode, a dimensionally stable anode (DSA electrode) and a plastic grid was used as separator, like is shown in Figure 2. The three-dimensional cathode was composed by a carbon felt $(1 \mathrm{~cm}$ thickness $)$ and a graphite plate as current collector. Likewise, a dimensionally stable anode is constituted by a ruthenium dioxide coating on a titanium electrode. In this sense, electro deposit of metallic ions is developed at cathode, although hydrogen is formed as competing reaction too. In the same way, formation of oxygen and protons by oxidation of water is obtained at anode and, then solutions are acidified during experiences.

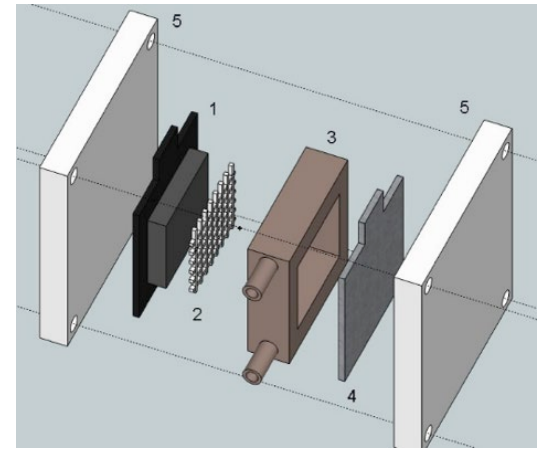

Figure 2. Scheme of a filter press electrochemical reactor:

1) three-dimensional cathode; 2) plastic grid; 3)

compartment; 4) dimensionally stable anode (DSA), and 5) clamping plates

In addition, leaching solutions from treatment of electronic waste and synthetic solutions with the same sulfuric medium $(\mathrm{pH}$ $\approx 1.5$ ) were used as starting solutions, so common initial composition is shown in table 1. Initially, one liter of leaching or synthetic solution was treated using current constant electrochemical experiences at 10,20 and $40 \mathrm{~mA} \cdot \mathrm{cm}^{-2}$ passing several times the theoretical charge necessary considering Faraday's law. Theoretical charge is expressed as $2 \mathrm{~F} \cdot \mathrm{mol}^{-1}$ ( $\mathrm{F}$ as Faraday constant) because all treated metals have valence 2, so 2 moles of electrons are needed per mole of electrodeposited metal, i.e., $2 \mathrm{~F}$ of charge per mole of electrodeposited metal. Solutions were pumped to the reactor using a peristaltic pump Heidolph model 5206 at a flow rate of $501 \cdot h^{-1}$. Note that, different strategies were developed for a selective metal recovery using leached solutions obtained and considering parameters such as charge passed and $\mathrm{pH}$. Likewise, $\mathrm{pH}$ was controlled in all experiences adding drops of $\mathrm{NaOH} 3 \mathrm{M}$ and it was measured in a continuous way using a $\mathrm{pH}$-meter Crison model micropH2000. Moreover, constant current was obtained using a power supply GWINSTEK model PSP-2010. Finally, metals in samples of leaching and treated solutions were analyzed by inductively coupled plasma (ICP) using a spectrometer Perkin Elmer model Optima 4300 DV.

\section{Results and Discussion}

3.1. Collection and physicochemical characterization of pins

First of all, a random collection of computing equipment of different companies, models and generation was carried out. 
Then, used pins in this work were manually disassembled from two different PCB's chosen in a random way. In Figure $3 a$ and $3 b$ PCB's before and after manual disassemble are shown. Moreover, in Figure 3c is shown the mixing of all kind of pins used in these experiments; a different morphology can be observed. For this reason, every pin was characterized by SEM-EDS.

After that, manual disassemble of every pin in the PCB's was performed. Each pin was meticulously characterized by SEMEDS using a JEOL scanning electron microscope model JSM6300 with a solid-state detector to perform energy dispersion semi-quantitative microanalysis. In addition, each solid obtained after leaching process was characterized by the same technique. Figure 3a shows images of PCB's before disassemble and Figure $3 \mathrm{~b}$ after disassemble, while Figure $3 \mathrm{c}$ shows the mixing of all pins used in the experiment; it can be observed that the pieces have different morphology; also these pieces were analyzed by SEMEDS.
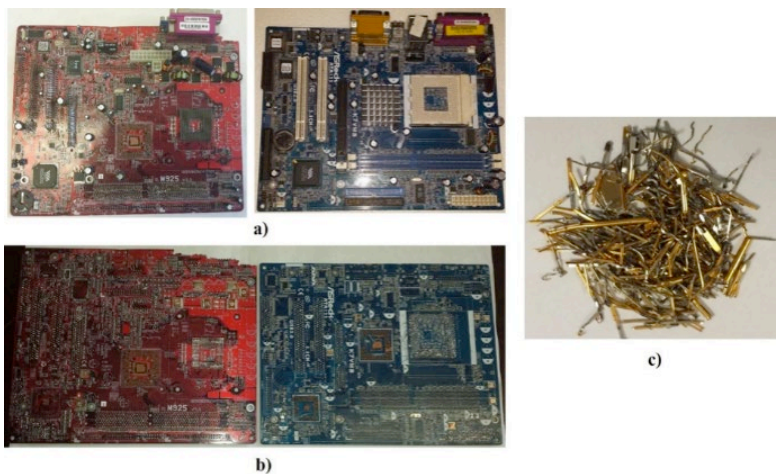

Figure 3. Photographs of PCB's used: a) before disassemble; b) after disassemble and c) mixture of different type of pins used in the experiment

According this, Figure 4 shows SEM micrographs, corresponding to different types of pins, and semi-quantitative microanalysis was performed taking three zones as references: i) upper zone, which is used to make contact with other electronic elements, ii) middle part, which is the body of the metallic element, and iii) bottom part, which connects with the base; semiquantitative microanalysis for different zones of different pins is similar so high quantity of gold is present in these pins. In Figure 5 , a representative EDS spectrum is shown and semi-quantitative microanalysis data is shown in table 1 and $79.12 \mathrm{wt} \%$ over a base of copper, nickel and zinc.

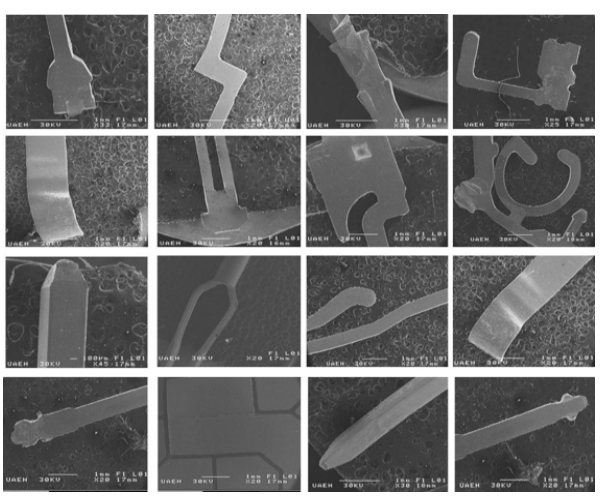

Figure 4. SEM micrographs of different type of pins

\begin{tabular}{cccccc}
\hline Element & k-ratio & ZAF & $\begin{array}{c}\text { Atom } \\
\%\end{array}$ & $\begin{array}{c}\text { Element } \\
\text { Wt } \%\end{array}$ & $\begin{array}{c}\text { Wt \% } \\
\text { Err. } \\
(1- \\
\text { Sigma) }\end{array}$ \\
\hline $\mathrm{Au}-\mathrm{L}$ & 0.7500 & 1.055 & 57.51 & 79.12 & $+/-3.38$ \\
$\mathrm{Cu}-\mathrm{K}$ & 0.0891 & 0.849 & 17.03 & 7.56 & $+/-0.80$ \\
$\mathrm{Zn}-\mathrm{K}$ & 0.0683 & 0.796 & 11.91 & 5.44 & $+/-0.85$ \\
$\mathrm{Ni}-\mathrm{K}$ & 0.0222 & 1.871 & 5.02 & 4.16 & $+/-0.60$ \\
$\mathrm{~Pb}-\mathrm{L}$ & 0.0172 & 1.060 & 1.26 & 1.82 & $+/-1.34$ \\
$\mathrm{Sn}-\mathrm{L}$ & 0.0072 & 1.755 & 6.42 & 1.26 & $+/-0.17$ \\
$\mathrm{Ag}-\mathrm{L}$ & 0.0032 & 2.023 & 0.85 & 0.64 & $+/-0.64$ \\
Total & - & - & 100.00 & 100.00 & - \\
\hline
\end{tabular}

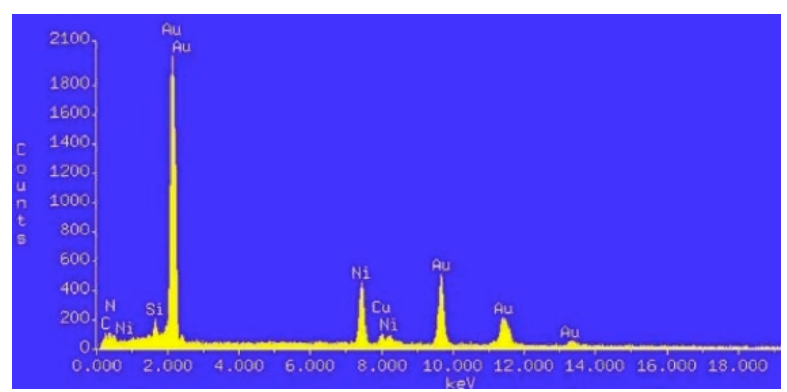

Figure 5. Representative energy - dispersive spectrum of pins (SEM-EDS)

3.2. Leaching of gold from pins, using sulfuric acid-oxygen. Recovery of gold in metallic state.

After physicochemical characterization of collected pins, experiments of dynamic acid leaching at 288, 298, 303, 308, 313, $318,323,333$ and $343 \mathrm{~K}$ were carried out as it was described in section 2.2. In this sense, recent studies have confirmed temperature is one of the most important factors influencing metal leaching/extracting from electronic waste (Tuncuk et al., 2012), (Mooiman et al., 2005). As known, the kinetic parameter for determining the type of control of a chemical reaction in the activation energy $\left(E_{a}\right)$, which is related to the temperature and reaction rate constant according to Arrhenius equation.

$$
\ln k=\ln A\left[-\frac{E_{a}}{R T}\right]
$$

However, experimental rate constant $k_{\text {exp }}$ are required previously to this calculation, so concentrations of $\mathrm{Cu}, \mathrm{Ni}$ and $\mathrm{Zn}$ versus time were plotted as is shown in Figures 6, 7 and 8. In this case, a first order reaction rate can be supposed and experimental reaction rate constants for each metal at different temperatures can be found.

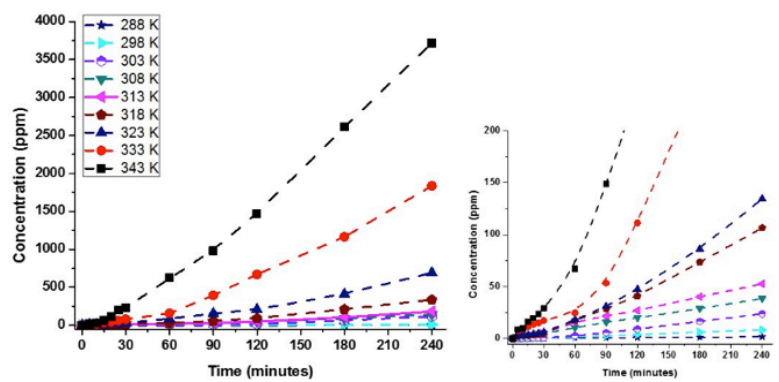

Figure 6. $\mathrm{Cu}$ concentration versus time plots 


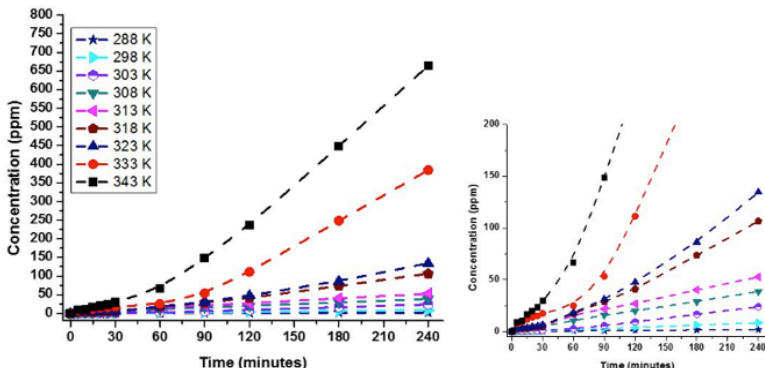

Figure 7. Ni concentration versus time plots

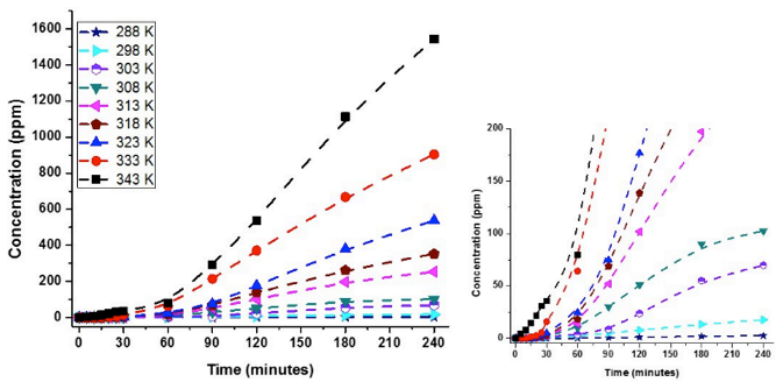

Figure 8. Zn concentration versus time plots

Table 2: Semi-quantitative microanalysis data from EDS spectrum of

\begin{tabular}{ccccc}
\hline $\begin{array}{c}\text { Temperature } \\
(\mathrm{K})\end{array}$ & $1 / \mathrm{T}(\mathrm{K})$ & $\begin{array}{c}\mathrm{K} \exp \mathrm{Cu} \\
\left(\mathrm{min}^{-1}\right)\end{array}$ & $\begin{array}{c}\mathrm{K}_{\exp } \\
\left(\mathrm{min}^{-1}\right)\end{array}$ & $\begin{array}{c}\mathrm{K}_{\exp } \\
\left(\mathrm{min}^{-1}\right)\end{array}$ \\
\hline 288 & 0.00347 & -3.6542 & -4.5008 & -4.8400 \\
298 & 0.00335 & -2.1593 & -3.0606 & -3.3131 \\
303 & 0.00330 & -1.1946 & -2.4382 & -3.0318 \\
308 & 0.00324 & -0.6025 & -1.8446 & -2.3750 \\
313 & 0.00319 & -0.3930 & -1.2823 & -1.8230 \\
318 & 0.00314 & 0.2582 & -0.6262 & -1.3080 \\
323 & 0.00309 & 0.9845 & -0.1576 & -0.6240 \\
333 & 0.00300 & 1.9986 & 0.8108 & -0.0899 \\
343 & 0.00291 & 3.0169 & 1.8671 & 0.9933 \\
\hline
\end{tabular}

Obviously, these values are increased when temperature increases. After obtaining natural logarithm of experimental reaction rate constants $\left(\ln \left[\mathrm{K}_{\text {exp }}\right]\right.$ in table 2$)$.

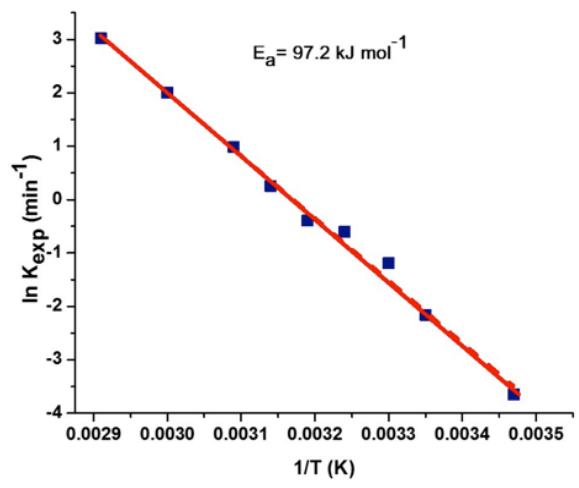

Figure 9. Arrhenius plot for $\mathrm{Cu}$ leaching process

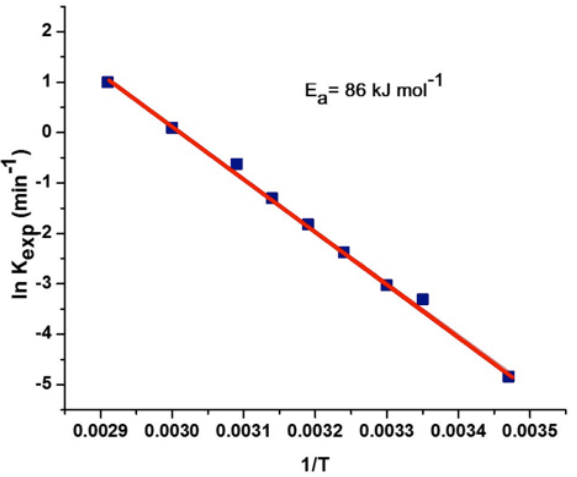

Figure 10. Arrhenius plot for Ni leaching process

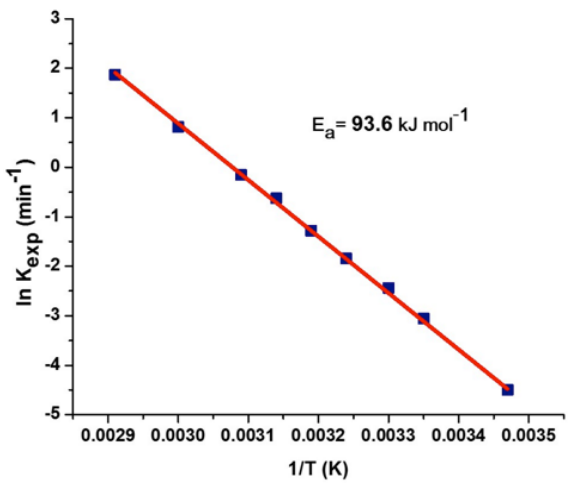

Figure 11. Arrhenius plot for $\mathrm{Zn}$ leaching process

Arrhenius plot was represented for $\mathrm{Cu}, \mathrm{Ni}$ and $\mathrm{Zn}$ leaching processes (Figures 9,10 and 11) and activation energies of 97.169 $\mathrm{kJ} \cdot \mathrm{mol}^{-1}$ for $\mathrm{Cu}, 86.033 \mathrm{~kJ} \cdot \mathrm{mol}^{-1}$ for $\mathrm{Ni}$, and $93.623 \mathrm{~kJ} \cdot \mathrm{mol}^{-1}$ for $\mathrm{Zn}$ were obtained, respectively. These high activation energies confirm temperature effect in leaching rate thus these values have to be considered as important parameters for setting leaching conditions.

Finally, considering a thermodynamic point of view, leaching reactions of $\mathrm{Cu}, \mathrm{Ni}$ and $\mathrm{Zn}$ using sulfuric acid and oxygen as oxidant/reducing agent in aqueous medium and its standard-state free energy $\left(\Delta \mathrm{G}^{\circ}\right)$ may be expressed in the following way (Behnamfard et al., 2013), (Birloaga et al., 2013), (Veglio et al., 2006):

$$
\begin{aligned}
& \mathrm{Cu}^{\circ}+\mathrm{H}_{2} \mathrm{SO}_{4}+\mathrm{H}_{2} \mathrm{O} \rightarrow \mathrm{Cu}^{2+}+\mathrm{SO}_{4}^{2-}+2 \mathrm{H}_{2} \mathrm{O} \\
& \Delta \mathrm{G}^{\circ}=-326.102 \mathrm{~kJ} \cdot \mathrm{mol}^{-1} \\
& \mathrm{Ni}^{\circ}+\mathrm{H}_{2} \mathrm{SO}_{4}+\mathrm{H}_{2} \mathrm{O} \rightarrow \mathrm{Ni}^{2+}+\mathrm{SO}_{4}^{2-}+2 \mathrm{H}_{2} \mathrm{O} \\
& \Delta \mathrm{G}^{\circ}=-423.604 \mathrm{~kJ} \cdot \mathrm{mol}^{-1} \\
& \mathrm{Zn}^{\circ}+\mathrm{H}_{2} \mathrm{SO}_{4}+\mathrm{H}_{2} \mathrm{O} \rightarrow \mathrm{Zn}^{2+}+\mathrm{SO}_{4}^{2-}+2 \mathrm{H}_{2} \mathrm{O} \\
& \Delta \mathrm{G}^{\circ}=-535.405 \mathrm{~kJ} \cdot \mathrm{mol}^{-1}
\end{aligned}
$$

As is shown, oxidation reaction is highly exothermic and it must be very careful with the temperature control. 


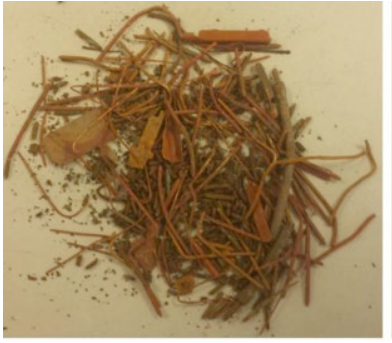

a)

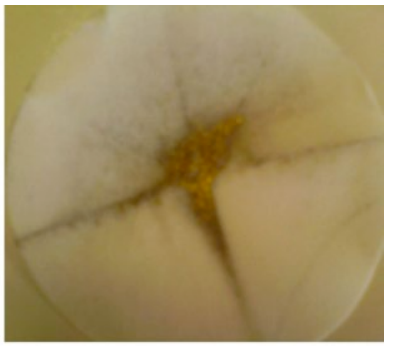

b)
Figure 12. Photograph of the products of the acid dynamic leaching of golden components. Total leaching time of 240 minutes: a) leached pins and b) gold particles

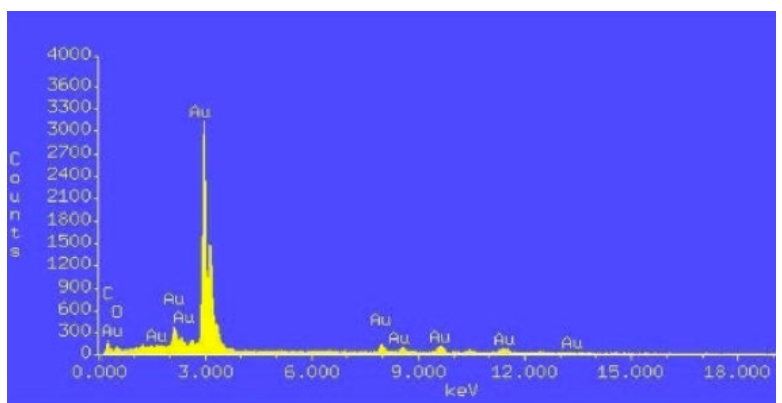

Figure 13. EDS spectrum of solid obtained after leaching of pins

Furthermore, pieces of solid gold completely separated from pins were observed at the end of experiments and a complete gold extraction was obtained from a temperature of $318 \mathrm{~K}$. In Figure $12 \mathrm{a}$, solid residue from pins leaching process is shown and metallic gold pieces of purity around $100 \%$ are shown in Figure 12b. Purity of this gold was checked by two techniques: EDS spectrum (Figure 13) and AAS Analysis from complete dissolution of solids. Finally, $\mathrm{Cu}, \mathrm{Ni}, \mathrm{Zn}$ and $\mathrm{Pb}$ leaching solution was obtained, their composition is shown in table 3 .

\begin{tabular}{|c|c|}
\hline Metal & $\begin{array}{c}\text { Concentration } \\
(\mathrm{ppm})\end{array}$ \\
\hline $\mathrm{Cu}$ & 270 \\
\hline $\mathrm{Ni}$ & 60 \\
\hline $\mathrm{Zn}$ & 60 \\
\hline $\mathrm{Pb}$ & 16 \\
\hline
\end{tabular}

3.3. Removal of non-precious metals from leaching solution using electrochemical processes.

In principle, two types of solutions have been synthesized: on the one hand, leaching solution obtained by treatment of electronic waste and synthetic solution obtained by solution of $\mathrm{Cu}, \mathrm{Ni}, \mathrm{Zn}$ and $\mathrm{Pb}$ in sulfuric medium at $\mathrm{pH} \approx 1.5$. At the end, initial concentration of ions are the same in both solutions as it is pointed out above in table 3 .

Then, electrochemical treatment of synthetic solution was carried out using three current densities of 10,20 and $40 \mathrm{~mA} \cdot \mathrm{cm}^{-}$ ${ }^{2}$. The same charge was passed in each current density (several times theoretical charge $-2 \mathrm{~F} \cdot \mathrm{mol}^{-1}$ considering Faraday's law) but, obviously, this charge is passed in different time. Evolution of metal concentration (in ppm) versus time is shown in Figure 14. Clearly, total $\mathrm{Cu}$ removal and no removal $\mathrm{Zn}$ and $\mathrm{Ni}$ are observed for any of the current densities but selective removal of lead is observed when current density is increased. Total lead electrodeposited $(0.2 \mathrm{ppm} \mathrm{Pb}$ in treated solution) was obtained when current densities of 20 and $40 \mathrm{~mA} \cdot \mathrm{cm}^{-2}$ were used (Figures
$14 \mathrm{a}$ and 14b) but a decreasing of around $50 \%$ in lead concentration (9 ppm $\mathrm{Pb}$ in treated solution) was obtained when current density was $10 \mathrm{~mA} \cdot \mathrm{cm}^{-2}$ (Figure 14c). This fact could be due to that cathodic electrode potential is lower (in absolute value) for $10 \mathrm{~mA} \cdot \mathrm{cm}^{-2}$ than for 20 and $40 \mathrm{~mA} \cdot \mathrm{cm}^{-2}$, therefore electrode potential cannot be enough negative for current density of 10 $\mathrm{mA} \cdot \mathrm{cm}^{-2}$ so dissolution rate of lead can be higher for this current density than for the other current densities. In the same way, we must to choose an appropriate current density for our process but, when we focus in Figure 14 (where concentration is plotted versus time) it is no possible, so another graphic representation must to be made.

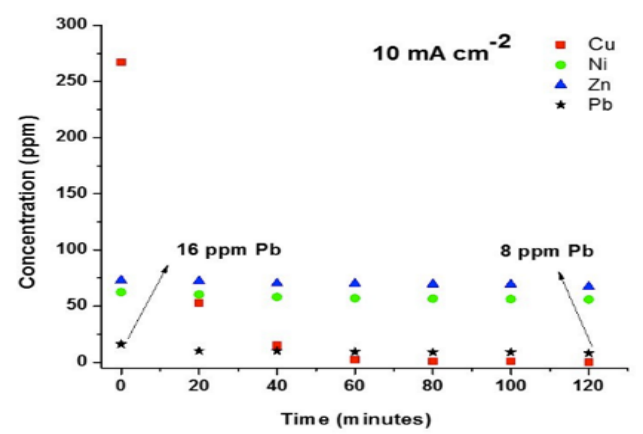

a)

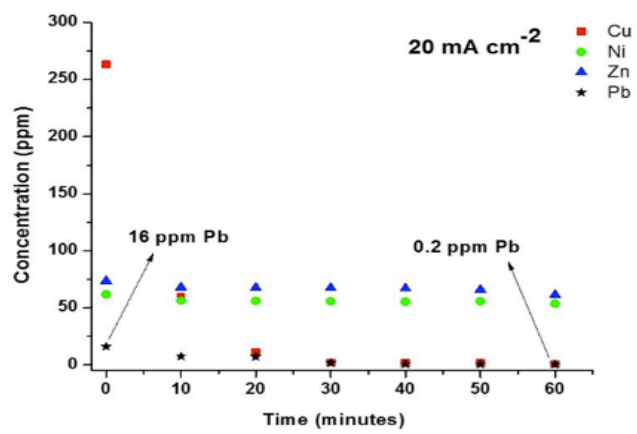

b)

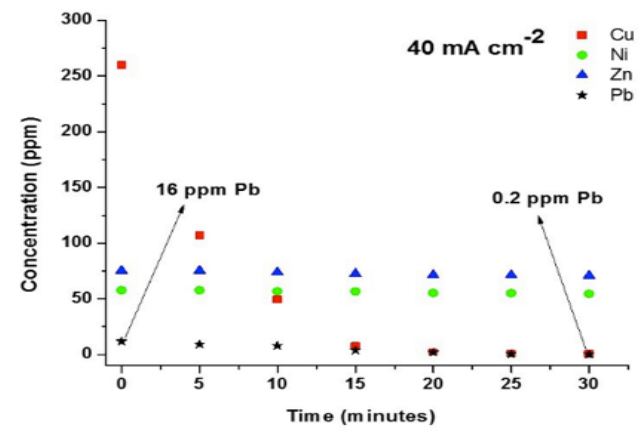

c)

Figure 14. Concentration of metals versus time at different current densities: a) 10 ; b) 20 ; and c) $40 \mathrm{~mA} \cdot \mathrm{cm}^{-2}$. Synthetic solution $260 \mathrm{ppm}$ of $\mathrm{Cu}, 60 \mathrm{ppm}$ of $\mathrm{Ni}, 60 \mathrm{ppm}$ of $\mathrm{Zn}$ and $16 \mathrm{ppm}$ of $\mathrm{Pb}$ in sulfuric acid medium at $\mathrm{pH}$ of 1.5 


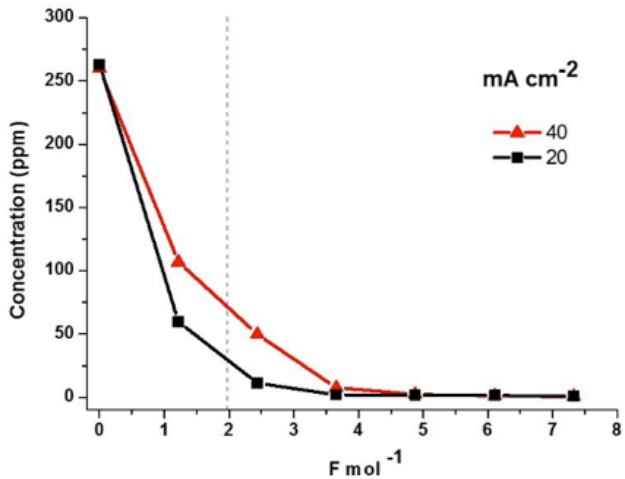

Figure 15. $\mathrm{Cu}$ concentration versus $\mathrm{F} \cdot \mathrm{mol}^{-1}$, as charge unit; experiences carried out at 20 and $40 \mathrm{~mA} \cdot \mathrm{cm}^{-2}$. Sulfuric medium at $\mathrm{pH}$ of 1.5

For this reason, $\mathrm{Cu}$ concentration was plotted versus $\mathrm{F} \cdot \mathrm{mol}^{-1}$, charge unit (Figure 15), and $20 \mathrm{~mA} \cdot \mathrm{cm}^{-2}$ has been chosen as an appropriate current density. Furthermore, comparison between treatment of synthetic and leaching solutions are shown in Figure 16 and identical behavior is observed in both. Accordingly, electrochemical treatment at $\mathrm{pH} 1.5$ produces removal of copper and lead in solution at $20 \mathrm{~mA} \cdot \mathrm{cm}^{-2}$, and copper electro deposit with less amount of lead was carried out at $10 \mathrm{~mA} \cdot \mathrm{cm}^{-2}$. $\mathrm{Zn}$ and $\mathrm{Ni}$ cannot be removed and a treated solution with these metals was obtained in both cases.

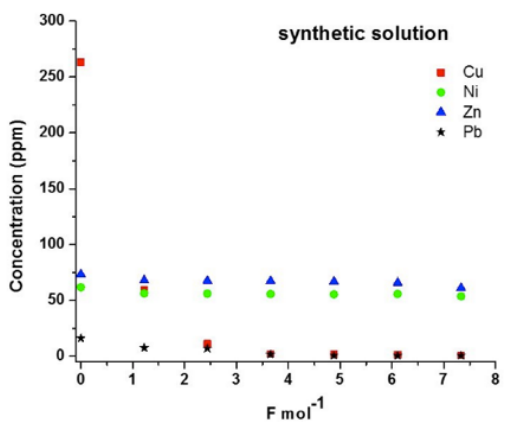

a)

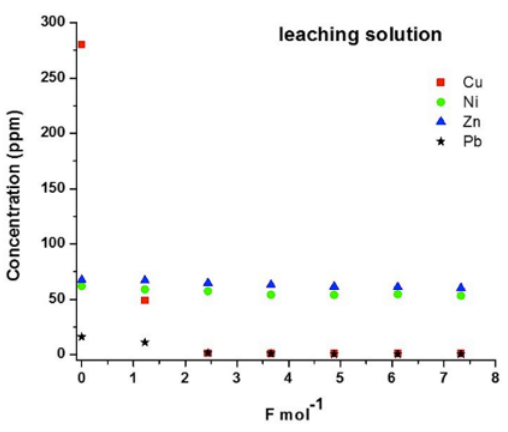

b)

Figure 16. Comparison between synthetic and leaching solutions treatment; a) Synthetic solution and b) Leaching solution: Current density of $20 \mathrm{~mA} \cdot \mathrm{cm}^{-2}$

In order to removal $\mathrm{Zn}$ and $\mathrm{Ni}$ from synthetic treated solution, $\mathrm{pH}$ solution was increased to a value of 3 adjusting with $\mathrm{NaOH}$ $3 \mathrm{M}$, and the solution was filtered. No difference in metal concentration has been detected between before and after filtered solutions. Afterwards, a second constant current electrochemical treatment was carried out at $20 \mathrm{~mA} \cdot \mathrm{cm}^{-2}$ passing several times the theoretical charge considering Faraday's law. In Figure 17, $\mathrm{Zn}$ and $\mathrm{Ni}$ concentration in ppm is plotted versus $\mathrm{F} \cdot \mathrm{mol}^{-1}$. As is shown, non-selective electro deposit of $\mathrm{Ni}$ and $\mathrm{Zn}$ is obtained as it was described in literature (Elkhabati et al., 1999), (Gómez et al., 2001), (Gómez and Válles, 1997), (Miranda et al., 1996), (Velichenko et al., 2000) and too much charge is necessary to removal $\mathrm{Ni}$ and $\mathrm{Zn}$ from solution. For this reason, this second electrochemical treatment was rejected. Similarly, $\mathrm{pH}$ of initial treated solution has been increased to 5, after solution was filtered and no difference in metal concentration was detected too. In the same way, electrochemical treatment at $20 \mathrm{~mA} \cdot \mathrm{cm}^{-2}$ was carried out (Figure 18). In this case, co-electro deposit of $\mathrm{Ni}$ and $\mathrm{Zn}$ is observed too, and significantly less charge is necessary for removing both metals. This is caused because $\mathrm{pH}$ increasing causes a decrease of hydrogen formation (competing reaction) and, thus electro-deposition yield is increased. After that, suitability of electrochemical treatment has to be verified using a leaching treated solution and the same procedure (Figure 19). Certainly, no difference is detected when Figure 18 (synthetic treated solution) and Figure 19 (leaching treated solution) are compared. Therefore, this is a good electrochemical treatment to obtain clear effluent $(<1 \mathrm{ppm}$ in metals studied $)$ with a selective removal of metals. Obviously, this effluent can be reused in the process if sulfuric acid is added.

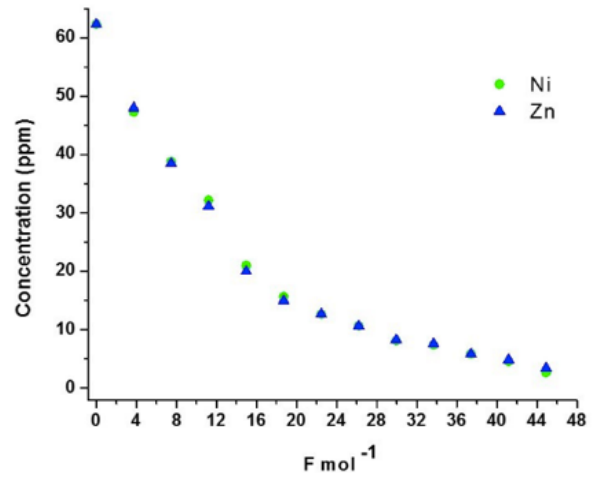

Figure 17. Metal concentration versus $\mathrm{F} \cdot \mathrm{mol}^{-1}$; synthetic treated solution after first electrochemical treatment and increased $\mathrm{pH}$ up to 3 with a current density of $20 \mathrm{~mA} \cdot \mathrm{cm}^{-2}$

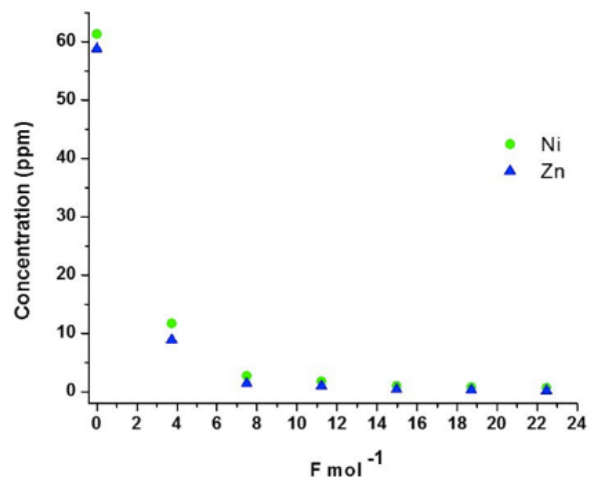

Figure 18. Metal concentration versus $\mathrm{F} \cdot \mathrm{mol}^{-1}$; synthetic treated solution after first electrochemical treatment and increased $\mathrm{pH}$ up to 5 with a current density of $20 \mathrm{~mA} \cdot \mathrm{cm}^{-2}$ 


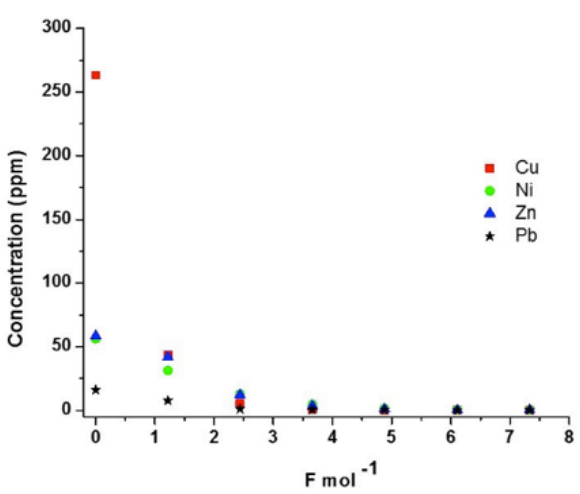

Figure 19. Metal concentration versus $\mathrm{F} \cdot \mathrm{mol}^{-1}$; leaching solution after first electrochemical treatment and increased pH up to 5 with a current density of $20 \mathrm{~mA} \cdot \mathrm{cm}^{-2}$

Finally, a new strategy can be proposed when a no selective removal of metals is required: $\mathrm{pH}$ of initial leaching solution has been increased from 1.5 to 5 , solution has been filtered, no difference in metal concentration has been tested and constant current electrochemical treatment at $20 \mathrm{~mA} \cdot \mathrm{cm}^{-2}$ has been carried out. As can be seen in Figure 20, total non selective removal of metals is shown, clean effluent $(<1 \mathrm{ppm}$ in metals studied $)$ is obtained and this effluent can be reused in the same manner as mentioned above. In summary, electrochemical treatment of leaching solution of non-precious metals allows choose strategies for a selective recovery of metals that can be obtained as shown in Figure 21.

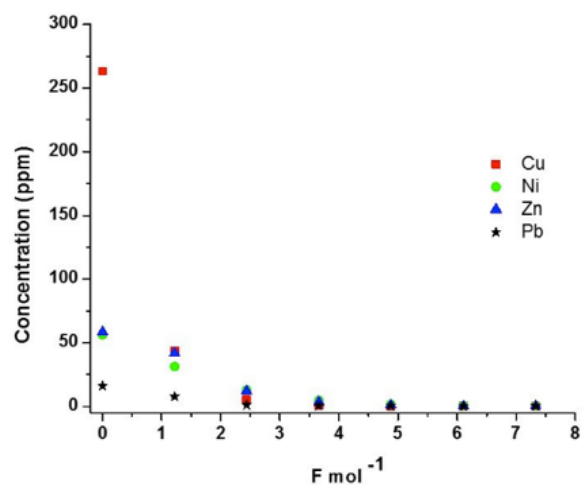

Figure 20. Metal concentration versus $\mathrm{F} \cdot \mathrm{mol}^{-1}$; leaching solution increasing $\mathrm{pH}$ from 1.5 to 5 , with a current density of $20 \mathrm{~mA} \cdot \mathrm{cm}^{-2}$

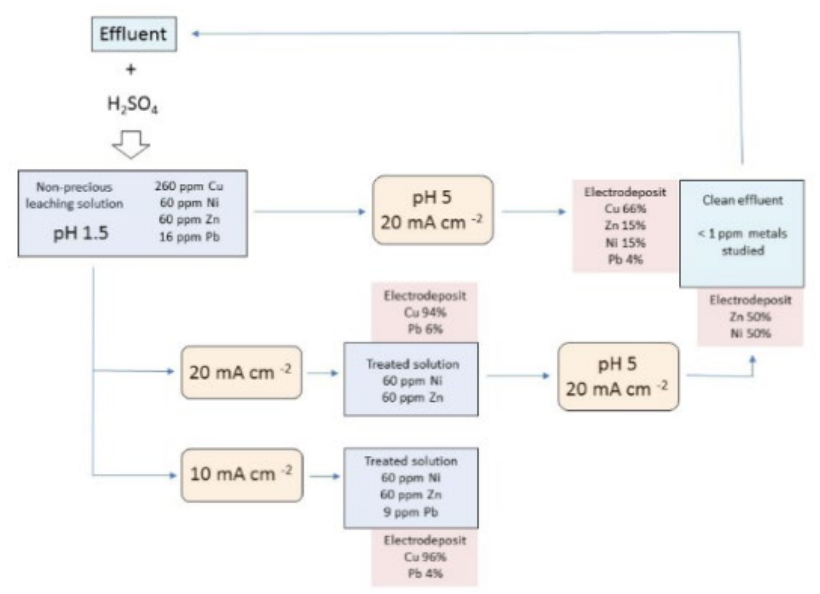

Figure 21. Scheme of different strategies for selective removal of metals

\section{Conclusions}

First of all, nailed pins were collected from PCB's after manual disassembly. Then physicochemical characterization by SEM-EDS of the pins were carried out and, mainly, $79 \mathrm{wt}$ $\% \mathrm{Au}, 7$ wt $\% \mathrm{Cu}, 5$ wt $\% \mathrm{Ni}, 4$ wt $\% \mathrm{Zn}$ and 2 wt $\% \mathrm{~Pb}$ composition were obtained. Substrate compound by $\mathrm{Cu}, \mathrm{Ni}$ and $\mathrm{Zn}$, but $\mathrm{Au}$ weight percentage is $79 \%$ over a base of copper, nickel and zinc.

After that, pins were treated using $\mathrm{H}_{2} \mathrm{SO}_{4} 0.5 \mathrm{M} / \mathrm{O}_{2}$ leaching at several temperatures. Golden solid product with purity higher than $99 \%$ and a leaching solution of $\mathrm{Cu}, \mathrm{Ni}, \mathrm{Zn}$ and $\mathrm{Pb}$ were obtained at the end of experiments. In these experiments, activation energies values of $97.2,86$ and $93.6 \mathrm{~kJ} \cdot \mathrm{mol}^{-1}$ for $\mathrm{Cu}$, $\mathrm{Ni}$ and $\mathrm{Zn}$ leaching were calculated; so temperature drastically influences in dissolution degree of elements and processes are controlled by chemical reaction.

In the same way, selective removal of non-precious metals, $\mathrm{Cu}$, $\mathrm{Zn}, \mathrm{Ni}$, and $\mathrm{Pb}$, from $\mathrm{H}_{2} \mathrm{SO}_{4} /$ Oxygen leaching solutions using electrochemical processes at different current densities and $\mathrm{pH}$ was carried out. Firstly, total copper removal from leaching solution (and synthetic solution) at $\mathrm{pH} 1.5$ was obtained using current densities of 10, 20 and $40 \mathrm{~mA} \cdot \mathrm{cm}^{-2}$. Ni and $\mathrm{Zn}$ cannot be removed at this $\mathrm{pH}$ using any current density. In addition, total $\mathrm{Pb}$ removal at $10 \mathrm{~mA} \cdot \mathrm{cm}^{-2}$ and partial removal of $\mathrm{Pb}$ at 20 and 40 $\mathrm{mA} \cdot \mathrm{cm}^{-2}$ were obtained. For this reason, a non-selective removal of metals was carried out at this $\mathrm{pH}$ so we have an electrodeposited copper-lead alloy on the electrode and a final effluent with $\mathrm{Ni}$ and $\mathrm{Zn}$, which must be treated for a total removal of non-precious metals. In this case, final electrochemical treatment has been carried out at $\mathrm{pH} 5$, and a total removal of $\mathrm{Ni}$ and $\mathrm{Zn}$ from effluent is achieved. Therefore, a selective removal of non-precious metals is possible and we recover an electrode copper/lead alloy $(95 / 5)$ and nickel/zinc alloy (50/50) as well as a clean effluent at $\mathrm{pH} 5$ which can be reused. At the same way, a non-selective removal of non-precious metals using electro deposit process at $\mathrm{pH} 5$ can be accomplished and a final co-deposit on electrode of $\mathrm{Cu}, \mathrm{Zn}, \mathrm{Ni}$ and $\mathrm{Pb}$ and the same clean effluent is obtained.

In conclusion, this combined hydrometallurgical (leaching $\mathrm{H}_{2} \mathrm{SO}_{4} \quad 0.5 \quad \mathrm{M} / \mathrm{O}_{2}$ ) and electrochemical (cathodic electrodeposition process) process is a good option as friendly environmental treatment of electronic waste, due to the reuse of waste acid solution in the electrowinning process and also for subsequent leaching steps. We obtained gold with a high purity and non-precious metals such as copper, lead, and nickel-zinc alloy.

\section{Acknowledgements}

Authors thank the support of UAEH for the realization of this work. Thanks also goes in memoriam to Dr. Isauro Rivera Landero, forever our friend.

\section{Referencias}

Babel, S. and Kurniawan, T.A., (2003). Low-cost adsorbents for heavy metals uptake from contaminated water: A review. Journal of Hazardous Materials 97 (1-3), 219-243 DOI: 10.1016/S0304-3894(02)00263-7

Behnamfard, A., Salarirad, M.M. and Veglio, F., (2013). Process development for recovery of copper and precious metals from waste printed circuit boards with emphasize on palladium and gold leaching and precipitation. Waste Management 33 (11), 2354-2363. DOI: 10.1016/j.wasman.2013.07.017 
Birloaga, I., Michelis, I.D., Ferella, F., Buzatu, M. and Veglio, F., (2013). Study on the influence of various factors in the hydrometallurgical processing of waste printed circuit boards for copper and gold recovery. Waste Management, 33 (4), 935-941. DOI: 10.1016/j.wasman.2013.01.003

Blais, J.F., Djedidi, Z., Cheikh, R.B., Tyagi, R.D. and Mercier, C., (2008). Metals precipitation from Effluents: Review. Practice and Periodical of Hazardous, Toxic, and Radioactive Waste Management, 13 (3), 135. DOI:10.1061/(ASCE)1090-025X(2008)12:3(135)

Cayumil, R., Ikram-Ul-Haq, M., Khanna, R., Saini, R., Mukherjee, P.S., Mishra, B.K., Sahajwalla, V., (2018). High temperature investigations on optimising the recovery of copper from waste printed circuit boards. Waste Management, 73, 556-565. DOI: 10.1016/j.wasman.2017.01.001

Chen, G., (2004). Electrochemical technologies in wastewaters treatment. Separation and Purification Technology, 38 (1), 11-41. DOI: 10.1016/j.seppur.2003.10.006

Cho, B-G., Lee, J-C., and Yoo, K., (2018). Valuable Metal Recycling. Metals, 8 (354), 1-4. DOI: $10.3390 /$ met8050345

Coman, V., Robotin, B., Ilea, P., (2013). Nickel recovery/removal from industrial wastes: A review. Resourses, Conservation and Recycling, 73, 229-238. DOI: 10.1016/j.resconrec.2013.01.019

Cui, H. and Anderson, C., (2020). Hydrometallurgical Treatment of Waste Printed Circuits Boards: Bromine Leaching. Metals, 10 (462), 1-18. DOI: $10.3390 /$ met 10040462

Cui, J. and Zhang, L., (2008). Metallurgical recovery of metals from electronic waste: A review. Journal of Hazardous Materials, 158 (1-2), 228-256. DOI: 10.1016/j.jhazmat.2008.02.001

Dąbrowski, A., Hubicki, Z., Podkościelny, P. and Robens, E., (2004). Selective removal of the heavy metals ions from waters and industrial wastewaters by ion exchange method. Chemosphere, 56 (2), 91-106. DOI: 10.1016/j.chemosphere.2004.03.006

Dimitrakakis, E., Janz, A., Bilitewski, B. and Gidarakos, E., (2009). Small WEEE: Determining recyclables and hazardous substances in plastics. Journal of Hazardous Materials, 161 (2-3), 913-919. DOI: 10.1016/j.jhazmat.2008.04.054

Dutta, D., Panda, R., Kumari, A., Goel, S., Jha, M.K., (2018). Sustainable recycling process for metals recovery from used printed circuit boards (PCBs). Sustainable Materials and Technologies, 17, e00066. DOI: 10.1016/j.susmat.2018.e00066

Elkhatabi, F., Benballa, M. and Müller, C., (1999). Dependence of coating characteristics on deposition potential for electrodeposited $\mathrm{Zn}-\mathrm{Ni}$ alloys. Electrochemica Acta, 44 (10), 1645-1653. DOI: 10.1016/S00134686(98)00286-2

E. U. Directive, Official Journal of the European Union L, 37 (2002) 24

Friege, H., (2012). Review of material recovery from used electric and electronic equipment-alternative options for resource conservation. Waste management \& Research: The Journal for Sustainable Circular Economy vil. 30 issue 9, 3-16. DOI: 10.1177/0734242X12448521

Fu, F. and Wuang, Q., (2011). Removal of heavy metals ion from wastewaters: A review. Journal of Environmental Management, 92 (3), 407-418. DOI: 10.1016/j.jenvman.2010.11.011

Gómez, E., Alcobe, X. and Vallés, E., (2001). Characterisation of zinc + cobalt alloys phases obtained by electrodeposition. Journal of Electroanalytic Chemistry, 505 (1-2), 54-61. DOI: 10.1016/S0022-0728(01)00450-8

Gómez, E. and Vallés, E., (1997). Electrodeposition of zn + cobalt alloys: initiations and development of anomalous co-deposition. Journal of Electroanalytic Chemistry, 421 (1-2), 157-163. DOI: 10.1016/S002220728(96)04835-8

Guo, C., Wuang, H., Liange, W., Fu, J. and Yi, X., (2011). Liberation characteristics and physical separation of printed circuit board (PCB). Waste management, 31 (9-10), 2161-2166. DOI: 10.1016/j.wasman.2012.05.011

Ha, V.H., Lee, J.C., Jeong, J., Hai, H.T. and Jha, M.K., (2010). Thiosulfate leaching of gold from waste mobile phones. Journal of Hazardous Materials, 178 (1-3), 1115-1119. DOI: 10.1016/j.jhazmat.2010.01.099

Haccuria, E., Ning, P., Cao, H., Venkatesan, P., Jin, W., Yang, Y., Sun, Z., (2017). Effective treatment for electronic waste - Selective recovery of copper by combining electrochemical dissolution and deposition. Journal of Cleaner Production, 152, 150-156. DOI: 10.1016/j.jclepro.2017.03.112

Hadi, P., Xu, M., Lin, C.S.K., Hui, C.W. and McKay, G., (2015). Waste printed circuit boards recycling techniques and product utilization. Journal of Hazardous Materials, 238, 234-243. DOI: 10.1016/j.jhazmat.2014.09.032

Hahladakis, J.N., Stylianos, M. and Gidarakos, E., (2013). Assessment of released heavy metals from electrical and electronic equipment (EEE) existing in shipwrecks through laboratory-scale simulation reactor. Journal of Hazardous Materials,

250-251,

256-264.

DOI: 10.1016/j.jhazmat.2013.02.005

He, W., Li, G., Ma, X., Wang, H., Huang, J., Xu, M. and Huang, C., (2006) WEEE recovery strategies and the WEEE treatment status in China. Journal of Hazardous Materials, 136 (3), 502-512. DOI: 10.1016/j.jhazmat.2006.04.060

Herat, S. and Agamuthu, P., (2012). E-waste: a problem or an opportunity? Review of issues, challenges and solutions in Asian countries. Waste Management \& Research: The Journal for a Sustainable Circular Economy, 30, 1113. DOI: 10.1177/0734242X12453378

Ișildar, A., Rene, E.R., van Hullebusch, E.D., Lens, P.N.L., (2018). Electronic waste as a secondary source of critical metals: Management and recovery technologies. Resources, Conservation \& Recycling, 135, 296-312. DOI: 10.1016/j.resconrec.2017.07.031

Kasper, A.C., Carrillo, J., García, M., Viet, H.M., and Pérez, V., (2016). Determination of the potential gold electrowinning from an ammoniacal thiosulphate solution applied to recycling of printed circuit board scraps. Waste Management \& Research, 34 (1), 47-57. DOI: 10.1177/0734242X15607425

Lee, C.H., Chang, C.T., Fan, K.S. and Chang T.C., (2004). An overview of recycling and treatment of scrap computers. Journal of Hazardous Materials, 114 (1-3), 93-100. DOI: 10.1016/j.jhazmat.2004.07.013

Li, H., Eksteen, J., Oraby, E., (2018). Hydrometallurgical recovery of metals from waste printed circuit boards (WPCBs): Current status and perspectives - A review. Resources, Conservatin \& Recycling, 139, 122 129. DOI: $10.1016 /$ j.resconrec.2018.08.007

Li, J., Lu, H., Guo, J., Xu, Z. and Zhuo, Y., (2007). Recycle Technology for Recovering Resources and Products from Waste Printed Circuit Boards. Environmental Science \& Technology, 41(6), 1995-2000. DOI: 10.1021/es0618245

Liu, X., Tan, Q., Li, Y., Xu, Z., Chen, M., (2017). Copper recovery from waste printed circuit boards concentrated metal scraps by electrolysis. Front. Environ. Sci. Eng., 11 (5), 1-5. DOI: 10.1007/s11783-017-0997-4

Long, Y.Y., Feng, Y.J., Cai, S.S., Ding, W.X. and Shen, D.S., (2013). Flow analysis of heavy metals in a pilot-scale incinerator for residues from waste electrical and electronic equipment dismantling. Journal of Hazardous Materials, 261, 427-434. DOI: 10.1016/j.jhazmat.2013.07.070

Memon, A.H., Patel, R.L., Pitroda, J., (2017). Design for recovery of precious and base metals from E-waste using electrowinning process. International Journal of Advance Research in Engineering, Science \& Technology, 4 (5), 579-587.

Miranda, F.J.F., Barcia, O.E., Diaz, S.L., Mateos, O.R. and Wiart, R., (1996). Electrodeposition of $\mathrm{Zn}-\mathrm{Ni}$ alloys in sulfate electrolytes. Electrochemica Acta, 41 (7-8), 1041-1049. DOI: 10.1016/0013-4686(95)00436-X

Mooiman, M.B., Sole, K.C. and Kinneberg, D.J., (2005). Challenging the traditional Hydrometallurgy curriculum - an industrial perspective. Hydrometallurgy, 79 (1-2), 80-88. DOI: 10.1016/j.hydromet.2004.11.013

Morera, E., (2004). Lixiviación de metales con ozono acuoso. Cinética de la plata y el oro. Aplicaciones. Ph. D. Thesis, Universitat de Barcelona, España (In Spanish).

Morf, L.S., Tremp, J., Gloor, R., Huber, Y., Stengele, M. and Zennegg, M., (2005). Brominated Flame Retardants in Waste Electrical and Electronic Equipment: Substance Flows in a Recycling Plant. Environmental Science \& Technology, 39(22), 8691-8699. DOI: 10.1021/es051170k

Reyes-Valderrama, M.I., Salinas-Rodríguez, E., Montiel-Hernández, J.F., Rivera-Landero, I., Cerecedo-Sáenz, E., Hernández-Ávila, J. and ArenasFlores, A., (2017). Urban Mining and Electrochemistry: Cyclic Voltammetry Study of Acidic Solutions from Electronic Wastes (Printed Circuit Boards) for Recovery of Cu, Zn, and Ni. Metals, 7 (55), 1-10. DOI: 10.3390/met7020055

Reyes, M.I., Rivera, I., Patiño, F., Flores, M.U. and Reyes, M., (2012). Total Recovery of Gold Contained in Computer Printed Circuit Boards. Leaching Kinetics of $\mathrm{Cu}, \mathrm{Zn}$ and Ni. Journal of the Mexican Chemical Society, 56 (2), 144-148. DOI: 10.29356/jmcs.v56i2.312

Sánchez, M.M., (2010). Cinética de lixiviación de $\mathrm{Cu}, \mathrm{Zn}$ y Ni, contenidos en circuitos impresos de computadora, Recuperación de oro. B.Sc. Thesis (In Spanish), Universidad Autónoma del Estado de Hidalgo, México.

Schluep, M., Hagelueken, C., Kuehr, R., Magalini, F., Maurer, C., Meskers, C., Mueller, E. and Wang F., (2009). Recycling: from E-waste to Resources. UNEP and United Nations University. $1-120$ https://www.researchgate.net/publication/278849195 Recycling from_e-waste_to_resources

Schwarzer, S., De Bono, A., Giuliani, G., Kluser, S. and Peduzzi, P., (2005). E-waste, the hidden side of IT equipment's manufacturing and use. Environment Alert Bulletin, 5, 1-5. https://archiveouvert.inige.ch/unige: 23132 
Sodhi, M.S. \& Reimer, B., (2001). Model for recycling electronics end-of-life products. OR-Spektrum, 23, 97-115. DOI: 10.1007/PL00013347

Sum, E.Y.L., (1991). The recovery of metals from electronic scrap. Journal Of Materials, 43, 53-61. DOI: 10.1007/BF03220549

Syed, S., (2006). A green technology for recovery of gold from non-metallic secondary sources. Hydrometallurgy, 82 (1-2), 48-53. DOI: 10.1016/j.hydromet.2006.01.004

Syed, S., (2012). Recovery of gold from secondary sources - A review. Hydrometallurgy, 115-116, 30-51. DOI: 10.1016/j.hydromet.2011.12.012

Tuncuk, A., Stazi, V., Akcil, A., Yazici, E.Y. and Deveci, H., (2012). Aqueous metal recovery techniques from e-scrap: Hydrometallurgy in recycling. Minerals Engineering, 25 (1), 28-37. DOI: 10.1016/j.mineng.2011.09.019

United States Environment Protection Agency, W.H.C.o.E.Q., 20 July 2011. National Strategy For Electronics Stewardship. Interagency Task Force on Electronics Stewardship, United States Environment Protection Agency US EPA. https://www.epa.gov/sites/production/files/201509/documents/national_strategy_for_electronic_stewardship_0.pdf

Veglio, F., Ferella, F., Michelis, I.De., Furlani, G., Navarra, M., Pagnanelli, F. \& Beolchini, F., (2006). Recovery of zinc and manganese from spent batteries. In Conference ECOMONDO Rimini Fiera, Italy, pp. 8-11

Velichenko, A.B., Portillo, J., Alcobé, X., Sarret, M. and Müller, C., (2000). Nature of anode passivation in $\mathrm{Zn}-\mathrm{Ni}$ electroplating baths. Electrochimica Acta, 46 (2-3), 407-414. DOI: 10.1016/S0013-4686(00)00599-5

Wan, X., Fellman, J., Jokilaakso, A., Klemettinen, L., and Marjakoski, M., (2018). Behavior of Waste Printed Circuit Board (WPCB) Materials in the Copper Matte Smelting Process. Metals, 8 (887), 1-10. DOI: $10.3390 /$ met8110887

Wang, H., Zhang, G., Hao, J., He, Y., Zhang, T., Yang, X., (2018). Morphology, mineralogy and separation characteristics of nonmetallic fractions from waste printed circuit boards. Journal of Cleaner Production, 170, 1501-1507. DOI: 10.1016/j.jclepro.2017.09.280
Wang, X. and Gaustad, G., (2012). Prioritizing material recovery for end-oflife printed circuit boards. Waste Management, 32 (10), 1903-1913. DOI: 10.1016/j.wasman.2012.05.005

Yang, D., Chu, Y., Wang, J., Chen, M., Shu, J., Xiu, F., Xu, Z., Sun, S., Chen, S., (2018). Completely separating metals and nonmetals from waste printed circuit boards by slurry electrolysis. Separation and Purification Technology, 205, 302-307. DOI: 10.1016/j.seppur.2018.04.069

Yang, H., Liu, J. and Yang, J., (2011). Leaching copper from shredded particles of waste printed circuit boards. Journal of Hazardous Materials, 187 (1-3), 393-400. DOI: 10.1016/j.jhazmat.2011.01.051

Zamboulis, D., Peleka, E.N., Lazaridis, N.K. and Matis, K.A., (2011). Metal ion separation and recovery from environmental sources using various flotation and sorption techniques. Journal of Chemical Technology and Biotechnology, 86 (3), 335-344. DOI: $10.1002 /$ jetb. 2552

Zhang, G., He, Y., Feng, Y., Zhang, T., Wang, H., Zhu, X., (2018). Recovery of residual metals from fine nonmetallic fractions of waste printed circuit boards using a vibrated gas-solid fluidized bed. Separation and Purification Technology, 207, 321-328. DOI: 10.1016/j.seppur.2018.06.017

Zheng, Y., Shen, Z., Ma, S., Cai, C., Zhao, X. and Xing, Y., (2009). A novel approach to recycling of glass fibers from nonmetal materials of waste printed circuit boards. Journal of Hazardous Materials, 170 (2-3), 978-982. DOI: 10.1016/j.jhazmat.2009.05.065

Zhuo, X., Guo, J., Lin, K., Huang, K. and Deng, J., (2013). Leaching characteristics of heavy metals and brominated flame retardants from waste printed circuit boards. Journal of Hazardous Materials, 246-247, 96-102. DOI: 10.1016/j.jhazmat.2012.11.065

Zhuo, Y. and Qiu, K., (2010). A new technology for recycling materials from waste printed circuit boards. Journal of Hazardous Materials, 175 (1-3) 823-828. DOI: 10.1016/j.jhazmat.2009.10.083 